VOI

27

IS S

12

$D F$

1984

UMI 

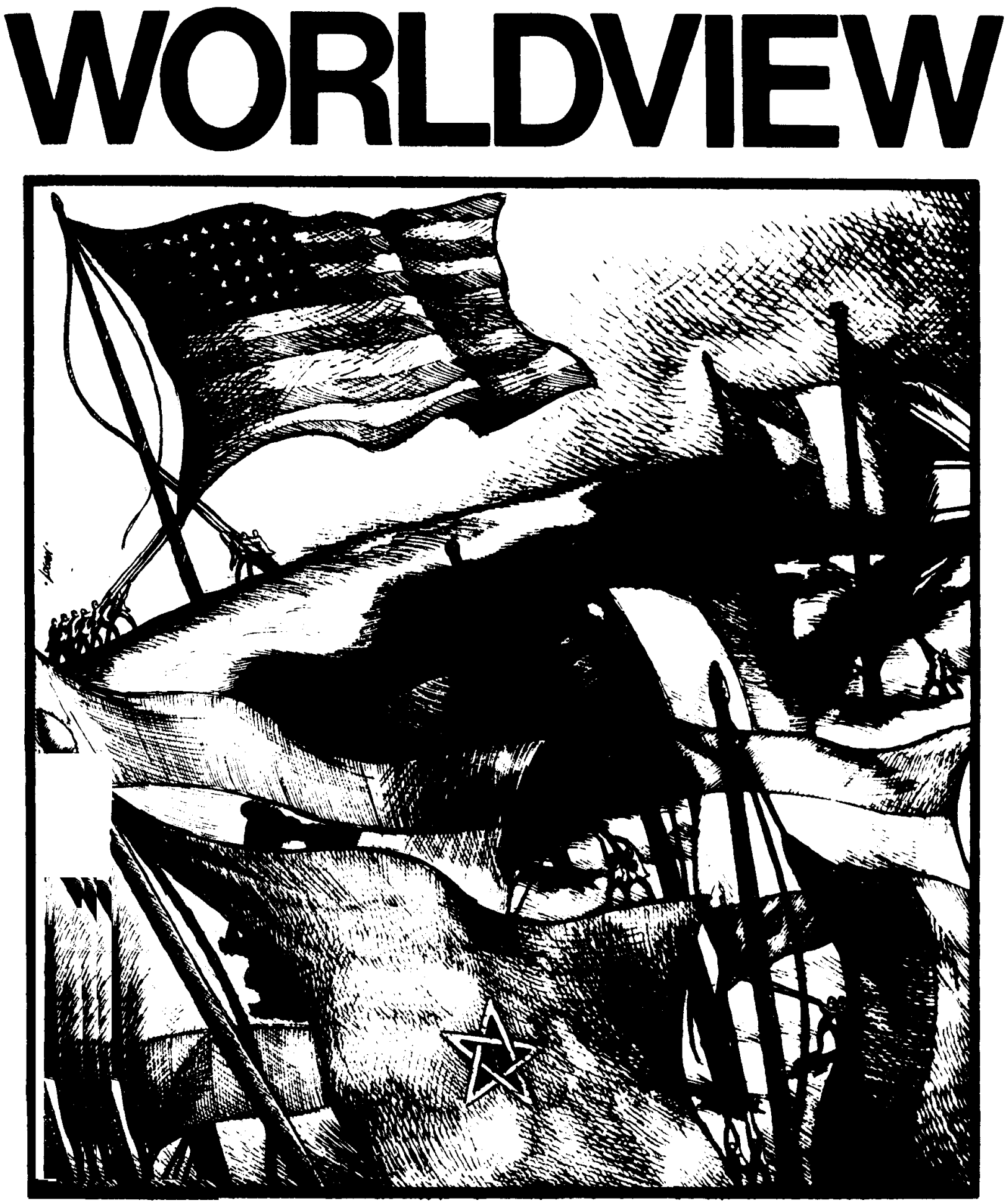

\section{IN THE NATIONAL INTEREST}

ARTHUR SCHLESINGER, JR.

THE DEBT CRISIS COMES HOME • MARC LEVINSON SPECIAL: AN INTERVIEW WITH BISHOP DESMOND TUTU

BOOKS: The Limits of Solidarity, on the 20th Century. the Hidden Imam, J. S. Mill Reconsidered 

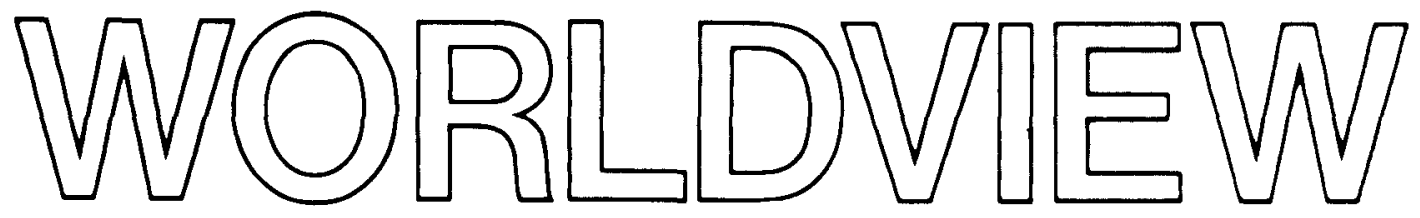

\section{EDITOR \\ John Tessitore \\ MANAGING EDITOR
Susan Wooltson
LITERARY EDITOR
John Becker \\ CONTRIBUTING EDITORS \\ Kofi Awoonor \\ Ross K. Baker \\ Mark A. Bruzonsky \\ Benjamin J. Cohen \\ Stephen S. Fenichell \\ Albert L. Huebner \\ Wilson Carey McWilliams \\ Paul Sigmund \\ EDITORIAL INTERN \\ Nancy E. Lorusso \\ DESIGN CONSULTANT \\ Robert W. Powell \\ BUSINESS MANAGER \\ Eva Becker \\ EDITORIAL BOARD \\ Walter E. Ashley \\ Robert W. Barnett \\ Eugene B. Borowitz \\ Robert F. Drinan, S.J. \\ Gerald Freund \\ J. Bryan Hehir \\ Robert J. Myers \\ Paul Ramsey \\ Seymour Siegel \\ Brian Thomas \\ Kenneth W. Thompson}

Cover Art: Ron Logan

\section{ARTICLES}

In the National Interest Arthur Schlesinger, Jr 5

Trade \& Jobs: The Brazilian Connection Marc Levinson

The Bishop \& South Africa: An Intervieu With Desmond Tutu

Rafael Suare:, Jr

\section{EXCURSUS}

India's Next Gandhi Trevor Fishlock 13

NATO at Thirty-Five Robert J. Myers... 14

Rumblings in the East Stephen Brockmann 15

Honduras Update Lucy Komisar...... 16

\section{COLUMNS}

Under Cover: Mrs. Gandhi: Legacy of a Nationalist

Wilson Carey McWillam: 2

Current Account: Paper Orphan Benjamin J Cohen 12

Listening In ......................... 21

\section{CORRESPONDENCE}

Lee Levitt, Martii Green

\section{BOOKS}

The Polish Challenge, by Kevin Ruane. The Polish Revolutuon

by Timothy Garton Ash Julian Crandall Hollick

Happiness, Justice \& Freedom: The Moral \& Polincal Philosoph of

John Stuart Mill, by Fred R. Berger William J Long 23

America Inside Out. by David Schoenbrun Ralph Buultjens 24

The Shadow of God and the Hidden Imam. by Sald Amir Arjomand

Patrick J Rian 25

Briefly Noted

\section{INDEX}

Volume 27, January-December. 1984

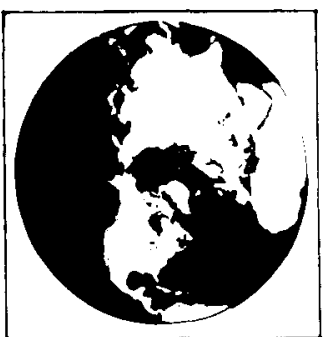

27th ANNIVERSARY
WORLDVIEWE is published monthly by the Council on Religion and international Athars Subscription- $\$ 25$ a year; $\$ 47$ for 2 years; $\$ 66$ for 3 years Student and Senior Cituzen rate $\$ 1250$ pe year. Add $\$ 5.00$ per year for Overseas postage Second-class postage pard at New Yonk $N Y$ and at additional entry offices. (ISSN 0084-2559)

Opinions expressed in WORLDVIEW are those of the authors and not necessarily of the Council on Fel gion and International Affairs. CCopyright 1984 Council on Religion and International Aftars a pubticty supported organization of the type described under sectiont $509(a)(1)$ and $170(b)(a)(A)(v)$ of the interna Revenue Code Unsolicited manuscripts must be accompanied by a stamped. sell-addressed retum enve lope. Letters to the Editor must include signature and address

Editorial \& Business \& Advertising Offices 170 E 64 Streel New York. N Y 10021 212838-4120 SuD scription Otfice and Change of Address: WORLDVIEW, PO. Box 1935, Manon, Onio 43305

POSTMASTER: Send address changes to WORLDVIEW. PO Box 1935 Manon Onio 43305 